\section{The sub-national economic and spatial development impacts of AGOA in Lesotho: An exploratory study}

\author{
Kelebone Lekunya \& Mark Oranje
}

http://dx.doi.org/10.18820/2415-0495/trp70i1.2

Peer reviewed and revised November 2016

\begin{abstract}
This exploratory study investigates the sub-national economic and spatial development outcomes of the African Growth and Opportunity Act, 2000 (AGOA) in Lesotho. The findings reveal that the settlements where the 'AGOA-factories' are located have experienced not only positive, but also significant negative economic and spatial impacts. While AGOA resulted in the creation of tens of thousands of job opportunities for unskilled and semi-skilled Basotho youth, it did not provide them with portable skills for use once they had left the AGOA factory floor. Neither did AGOA motivate the youth or local entrepreneurs to tap into the manufacturing sector. In terms of spatial development, the AGOA factories had led to infrastructure investment, essentially to serve the factories, which, in turn, also benefited the surrounding territories. In many of the settlements, rental units - unplanned and without planning permission - have been constructed in response to the huge demand for affordable housing by the thousands of migrant workers. While fulfilling a definite need, these units have simultaneously led to the development of monotonous 'sleeper towns', over-burdening of already strained municipal services, haphazard land development, and a feeling of 'anything goes'. The research findings suggest that, while 'trade and development boosting tools' such as AGOA may be useful in providing term-based job opportunities for an unskilled workforce, they will most likely not have as significant a positive impact on the local economy, the creation of an indigenous industrial class, or the building of sustainable human settlements.
\end{abstract}

Keywords: AGOA, Lesotho, sub-national spatial development impacts, sub-national economic development impacts

\section{DIE SUB-NASIONALE EKONOMIESE EN RUIMTELIKE ONTWIKKE- LINGSIMPAKTE VAN AGOA IN LESOTHO: 'N VERKENNENDE STUDIE}

Hierdie verkennende studie ondersoek die sub-nasionale ekonomiese en ruimtelike ontwikkelingsuitkomste van die African Growth and Opportunity Act, 2000 (AGOA) in Lesotho. Die bevindings van die studie dui daarop dat die nedersettings waar die 'AGOA-fabrieke' geleë is, positiewe, maar eweneens ook beduidende negatiewe ekonomiese en ruimtelike impakte ervaar het. Terwyl AGOA wel daarin geslaag het om tienduisende werksgeleenthede vir ongeskoolde en semi-geskoolde Basothojeug te skep, het dit hulle nie toegerus met draagbare vaardighede vir gebruik elders, nadat hulle die AGOA-fabrieksvloer verlaat het nie. Die studie het ook nie gevind dat AGOA plaaslike jeug of entrepreneurs gemotiveer het om in die vervaardigingsektor in te skakel nie. Wat betref ruimtelike ontwikkeling is daar gevind dat die AGOAfabrieke gelei het tot die investering in infrastruktuur wat essensieel is om die fabrieke te diens, wat in die proses ook nabygeleë gebiede bevoordeel het. In baie van die nedersettings is huureenhede - onbeplan en sonder beplanningstoestemming gebou in reaksie op die groot vraag na bekostigbare behuising onder die duisende trekarbeiders. Terwyl hierdie wooneenhede ' $n$ duidelike leemte gevul het, het hulle ook gelei tot die ontwikkeling van eentonige 'slaapdorpe', oorskreiding van die kapasiteit van reeds beperkte munisipale dienste, onbeplande grondontwikkeling, en 'n gevoel van 'laat maar gaan'. Die navorsingsbevindinge stel voor dat, terwyl 'instrumente wat daarop gerig is om handel en ontwikkeling te stimuleer', soos AGOA, nuttig kan wees in die skep van termyn-gebaseerde werksgeleenthede vir ' $n$ ongeskoolde werksmag, die instrumente heel waarskynlik nie ' $n$ soortgelyke positiewe impak sal hê op die plaaslike ekonomie, die totstandkoming van 'n inheemse industriële klas, of die daarstel van volhoubare nedersettings nie.
Sleutelwoorde: AGOA, Lesotho, subnasionale ruimtelike ontwikkelingsimpakte, sub-nasionale ekonomiese ontwikkelingsimpakte

\section{TSHUSUMETSO YA MORUO WA NAHA POTLANA (SUB- NATIONAL) LE NTSHETSOPELE YA SEPAKAPAKA (SPATIAL) AGOA KA HARE HO LESOTHO: THUTO E HLOHLOMISANG}

Ho fumana le ho boloka kgolo e tatileng ya moruo le kgolo e tswellang pele ya setjhaba le ntshetsopele ya sepakapaka (spatial),ka ho thea diindasteri e bile phepetso e phehelletseng lebatowa (region) la Sub-Saharan Africa (SSA). Tharollo e atisang ho tshwarwa, bakeng sa phepetso ena e bile ho fana ka tumello ya ho fumana thepa e entsweng ke lebatowa (region) la SAA bakeng sa dimmaraka tse fapaneng, tse phedisanang tsa Leboya (North). Bohlale bona bo bonahalang bo entse hore ho be le African Growth Opportunity Act (AGOA) ka selemo sa 2000, Sebokeng/ kopanong ya Dinaha tse kopaneng tsa Amerika (United States of America) ya bomakgolo a mabedi (200). Thutong ena ya ho hlohlomisa,boiphihlelo bo fumanweng ke naha ya Lesotho ka lebaka la AGOA, haholoholo re shebile ditlamorao tsa molao moruong wa naha potlana le ntshetsopeleng ya sepakapaka ka hara naha; bo a batlisiswa/hlwelwa. Diphumano/ diphetho tsa diphuputso tsa thuto ena di bontsha hore dibaka tsa bodulo tse kgolwanyane; moo difeme tsa AGOA di leng teng, di fihlelletse botle bo itseng; empa tshusumetso e bile mpe haholo moruong le sepakapakeng. Le hoja AGOA e entse hore ho be le mashome a dikete a menyetla ya mesebetsi bakeng sa batjha ba Basotho ba senang tsebo le ba nang le tsebo e nnyane, ha e a ka ya ba fa bokgoni bo lekaneng, boo ba ka bo sebedisang ha ba se ba tsamaile femeng. AGOA hape e ile ya fumanwa e sa fa batjha kapa borakgwebo ba selehae tshusumetso ya ho kena karolong ya diindasteri. Lehlakoreng la ntshetsopele ya sepakapaka, difeme tsa AGOA di fumanwe di etsa dibopeho tsa motheo (infrastructure); dipoloko (investment) haholoholo hore di sebeletse difeme tsena, hape ka lehlakoreng le leng, di molemong wa dibaka tse potapotileng moo. Dibakeng tse ngata tsa bodulo, diyuniti tsa khiro- tse sa rerwang le tse senang ditumello tsa ho aha- di ahilwe

The author declare no conflict of interest for this title or article.

Mr Kelebone Lekunya, Research Masters' degree student, Department of Town and Regional Planning, University of Pretoria, 0028, South Africa. Email: <klekunya@gmail.com>

Prof. Mark Oranje, Head of Department, Department of Town and Regional Planning, University of Pretoria, 0028, South Africa. Phone: 0829083418, email: <mark.oranje@up.ac.za> 
ka baka la thokeho e kgolo ya matlo a ka lefellwang ha bobebe ke dikete tsa basebeletsi ba bafalli (migrant workers). Ha ho ntse ho kwalwa sekgeo sena se bonahalang, diyuniti tsena ka yona nako eo di entse hore ho be le ntshetsopele/ ntlafatso ya ditoropo tse nnyane, boima bo boholo hodima ditshebeletso tsa masepala tse seng di imetswe, ntshetsopele/ntlafatso ya lefatshe le sa hlophiswang hantle le maikutlo a hore ntho e nngwe le e nngwe e lokile/e a etswa. Ka kakaretso, diphumano/ diphetho tsa dipatlisiso di hlahisa hore, leha kgwebo/thekiso (trade) le dithulosi (tools) tse tshehetsang ntshetsopele; jwaloka AGOA, di kanna tsa ba molemo tabeng ya ho fana ka menyetla ya mesebetsi ya nako e telele bakeng sa basebeletsi ba senang tsebo, di ka se be le tshusumetso e kaalo ya bohlokwa hodima: moruo wa selehae, ho thewa ha diindasteri tsa lehae, kapa kaho ya bodulo bo bolokehileng. Hore sena se tle se etsahale, dithulosi tsena ka botsona di tlameha ho tsepamiswa haholo ka nako e telele,hodima ntshetsopele e kopanetsweng ya dinaha tse tshwanetsweng ke ho una molemo mme ho kenyelletswa le ditlhoko tse hlahlamanang, tse lekantsweng ho ntshetsapele kgokahano e nang le boleng bakeng sa maemo a mangata a setjhaba. Ka kopanelo ya ho hlahisa dithulosi tsa matjhaba tse ntjha tsa kgwebo; sete ya disebediswa tsa selehae bakeng sa ho kgothatsa; ho hodisa le ho eketsa ntshetsopele dikgokahano tse kang tsena; di tlameha ho kopanelwa le ho tsejwa dinaheng tse tshwanetsweng ke ho una molemo.

\section{INTRODUCTION}

The achievement of rapid, inclusive and sustainable economic growth that is enabled by, and contributes to the development of dynamic, responsive, inclusive and resilient human settlement development, has been a long-standing objective and challenge for the countries in sub-Saharan Africa (SSA) (Vastveit, 2013: 1). A commonly held 'solution' to this challenge has been to emulate the Chinese manufacturing-and-trade-led success story and to secure access of manufactured goods from the SSA region to the dynamic markets of the affluent North (Poplak, 2012; Wroblewska, 2015). In accordance with this prevailing wisdom, the Congress of the United States of America (USA) enacted the African Growth and Opportunity Act (AGOA) in 2000 (Congress of the USA, 2000).
The main objectives of the Act were to facilitate duty and quota-free trade in designated goods between the USA and the SSA region and, in so doing, promote, support and strengthen economic growth, job creation, economic diversification, development, poverty reduction, democracy, the rule of law and stability in countries in the SSA region, and assist their integration into the global economy (Congress of the USA, 2000: 3-4; 2015: 2; Zappile, 2011: 50). Key in this regard was to 'reward' countries that pursued market-based economic policies, maintained clean human rights, labour and governance records, and did not "provide support for acts of international terrorism", or engaged in activities that posed a threat to the national security of the USA or its foreign policy interests (Congress of the USA, 2000: 4; Vastveit, 2013: 39; Kamara, 2008: 27).

Towards the end of AGOA's fifteenyear lifespan, opinions were divided as to its track record and whether it should be terminated, or given a further lease of life, and if so, what the timeframe of such an extension should be (Schneidman, 2013; 2015; Daily Monitor, 2013; IRIN, 2012; Williams, 2014). It was eventually extended for another ten years on 29 June 2015, with the signing into law of the AGOA Extension and Enhancement Act of 2015 by the then President Barack Obama (Congress of the USA, 2015; Francavilla, 2015).

Over the course of the (first) fifteen years of its existence, there has been a strong flow of exports from the SSA region to the USA, significantly increasing trade between the USA and the region (Kushner, 2015; Asafu-Adjaye, 2011: 38; Kamara, 2008: 27). Hundreds of thousands of direct jobs and millions of indirect jobs were also created, due to the establishment of 'AGOA factories' in the region (Kushner, 2015; Wroblewska, 2015). It was, however, not clear whether the rapid establishment of these factories had assisted in the creation of a sustainable manufacturing-led economic base in the region, one that could survive, flourish, transform and rejuvenate itself once AGOA was terminated. A key component of this question is whether 'the AGOAphase' had assisted in suitable, affordable and robust infrastructure investment, and liveable, viable and resilient settlement development in those towns/cities where the AGOA factories are located. This article deals with these fundamental questions, with a specific focus on the Kingdom of Lesotho.

The paper is structured as follows. The next section provides a brief overview of the impacts of AGOA on the SSA region. This is followed by a short introduction to Lesotho, a brief description of the specific areas in the country where the research was conducted, and the research methodology. The findings are then presented, followed by a discussion based on the key research questions, and finally the conclusion.

\section{OVERVIEW OF AGOA AND ITS IMPACTS ON THE SUB- SAHARAN AFRICA REGION}

By its nature, AGOA can be classified as falling under "preferential trade agreements” (PTAs) (Karingi, Páez \& Degefa, 2012: 1; Poplak, 2012). These are generally described as mechanisms or arrangements aimed at removing specific, or all tariff and non-tariff barriers between countries or large blocs/regions to enable them to trade (more) effectively with each other (Organisation for Economic Co-operation and Development (OECD), 2001). Often economically more powerful countries pursue these agreements to ensure economic development in economically less powerful countries, and by doing so, making cross-country migration relatively less attractive, weakening the likelihood of conflict and war, balancing trade balances and reducing the need for aid (Obasanjo, 2013; Smith, 2009; Biermann \& Oranje, 2002: 9-11). Often economically more powerful countries establish such agreements to secure privileged access to natural and human resources as well as foreign direct investment opportunities, develop or expand export markets, 'tie in' economically less powerful countries, and minimise 
the influence of contenders in emerging or economically attractive areas/regions (Kamara, 2008: 22-26; Biermann \& Oranje, 2002: 11-14). PTAs have been put in place on most continents, such as, for instance, the North American Free Trade Agreement (NAFTA), the Common Market for Eastern and Southern Africa (COMESA), and the South Asian Free Trade Area (SAFTA). PTAs also span continents, as in the case of the Trans-Pacific Partnership (TPP) and the proposed Transatlantic Trade and Investment Partnership (TTIP). In the case of AGOA, this arrangement relates to the USA and the SSA region.

\section{Although both USA and SSA} government officials have generally hailed AGOA as a highly effective tool for strengthening trade and development, there are mixed feelings about its benefit in other quarters (Poplak, 2012; Lenaghan, 2006: 119; Rotunno, Vezina \& Wang, 2012: 2; Hickel, 2016). Lenaghan (2006), for instance, argues that its enactment has been beneficial only to the USA and not to the SSA. $\mathrm{He}$ attributes this to the fact that both the eligibility factors and the processes of assessment of eligibility and termination of membership of a country are effected by the USA, with its interests at heart (Lenaghan, 2006: 119; Kamara, 2008: 37). Davis (2011: 1150-1151), Mushita (2001: 17) and McCormick (2006: 384) support this view and argue that AGOA gives the USA the upper hand, and that the SSA countries are not treated as equal partners, but rather as subordinates.

AGOA is also viewed as an interference in the internal affairs of SSA countries, which, according to Brooks and Shin (2006), stands in marked contrast to the Chinese development model, which generally comes without conditions regarding human rights and the nature of the domestic economy (i.e., free market or not). Hafner-Burton (2005: 595), on the other hand, argues that AGOA can for this exact reason be 'a force for good', contributing to the ending of abuse and gross violations of human rights in recipient countries by forcing prospective
AGOA participants to attend to such matters in decisive and enduring ways. The respect for human rights and the freedoms that the economic system supported by AGOA creates, in turn, also enable and encourage participation in the economy (HafnerBurton, 2005: 595).

Irrespective of the differences in opinions on the benefits of the Act, there is conclusive evidence that AGOA has, in addition to boosting exports of raw products (notably oil and minerals) from Africa, led to the construction of factories and the creation of huge numbers of jobs in these facilities (Keletso, 2015; Kushner, 2015; Rantaoleng, 2014: 9; Guest, 2010; Fosu, 2011: 119; Condon \& Stern, 2011: 39). ${ }^{1}$ AGOA has been a huge success, especially in the generally labourintensive textile sector where tens of thousands of unskilled and semi-skilled jobs have been created (Keletso, 2015; Morris \& Sedowski, 2006: 12). It has, however, been argued that the wages and salaries tied to these jobs have been far below the living wage, and as such only 'kept the workers going' from one day to the next, and have not enabled them to live decent and meaningful lives (Rotunno et al., 2012; Wax, 2003; Hickel, 2011). In addition, it has been argued that the majority of the factories in the SSA region were set up by Chinese and Taiwanese companies who have had little interest in developing the local population or imparting skills to them (Rotunno et al., 2012; Lall, 2005: 1008; Fosu, 2011). At the same time, this has meant that a large part of the benefit to be derived from AGOA by the non-USA trading partners has gone to the non-SSA companies and their home countries (Lall, 2005; Rotunno et al., 2012; Hickel, 2011; Kamara, 2008: 27). It has also been argued that the main interests of the Chinese companies in 'the AGOA project' have been to use the financial

\footnotetext{
1 Kushner (2015), for instance, observes that AGOA has created 350,000 direct jobs and increased annual USA-Africa trade from \$7billion to \$25billion, while Wroblewska (2015) puts the total number of new jobs created in Africa at 1.3 million, and Green (2013: online) reports that AGOA has "indirectly supported" a further 10 million jobs on the continent.
}

incentives offered by AGOA, and sidestep trade and tariff walls erected by the USA against imports from China, especially so in the clothing and textiles sector (Rotunno et al., 2012; Fosu, 2011; Poplak, 2012).

The vast majority of studies on AGOA, maybe given its countryto-country focus, have focused on the macro, country level. Research into the impact of AGOA on the spatial development of sub-national localities, the establishment of regional and local value chains, the beneficiation of primary products prior to export, and the development of indigenous industries on the back of AGOA, is, as far as we could establish, non-existent. In this regard, this study seeks to contribute to the field, by initiating a tentative, exploratory body of research into the sub-national (i.e., regional and local) spatial and economic development benefits of $A G O A,{ }^{2}$ with the Kingdom of Lesotho as the country in which the study was undertaken.

\section{THE STUDY AREA}

\subsection{Why Lesotho?}

Lesotho was designated as eligible for trade benefits under AGOA in October 2000, and satisfied the AGOA requirements in April 2001 (Central Bank of Lesotho, 2011: 1). Soon after this date, it started exporting "designated goods", as per the Act, in the form of textiles and apparels to the USA, which has noted the contribution of the sector to the country's GDP grow to approximately $20 \%$, and approximately 40,000 Basotho now working in AGOArelated clothing factories in the five industrial areas in the country (Keletso, 2015; AGOA.Info, 2016; England, 2014; Kamara, 2008: 47-48; USITC/Department of Commerce,

2 In this study, 'sub-national spatial development' is understood as the planned development and growth of settlements, the provision and construction of housing in accordance with a plan or guiding framework as well as the provision and maintenance or infrastructure and basic services in these settlements. Under 'sub-national economic development' is understood the development of indigenous industries, the establishment of regional and local value chains and the beneficiation of primary products prior to export. 


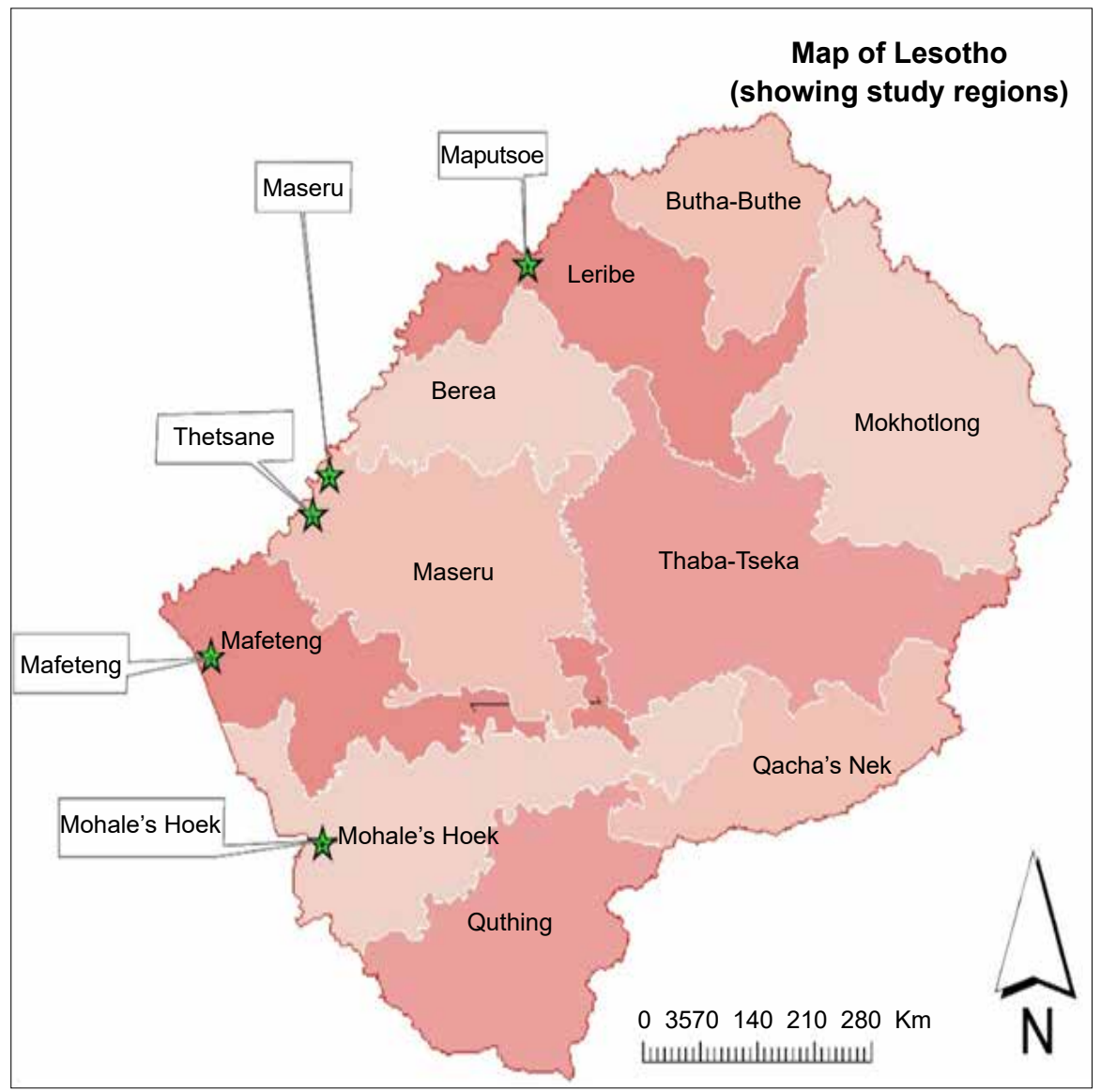

Figure 1: Location of the five industrial estates in Lesotho

Source: Google Earth (2015)

2015; Bureau of Statistics, 2015: 3). ${ }^{3}$ As such, it has become one of the largest exporters of clothing and textiles to the USA in terms of AGOA, and the single largest employer in the manufacturing sector in the country by far (Bureau of Statistics, 2015: 2; Hickel, 2016; England, 2014). ${ }^{4}$ Given the size, significance and rapid growth of these AGOA-related operations in the country (Condon \& Stern, 2011; Lall, 2005; Manoeli, 2012: 11; Payne, 2011; Vastveit, 2013: 67), it presents an ideal case to study the impact of the factories, established in response to the Act, on sub-national (regional and local) economic and spatial development in a beneficiary country, and to generate a better understanding of the contribution that PTAs such as AGOA

3 In 2007, at its peak and prior to the Global Economic Recession, 52,169 workers were employed in AGOA factories in Lesotho (Vastveit, 2013: 68)

4 Clothing brands that are manufactured in the country include Gap, Levi-Strauss and Walmart (Keletso, 2015) can make to the development of subnational spaces and economies. ${ }^{5}$

\subsection{Where in Lesotho?}

The study was undertaken in the five industrial estates of Lesotho in which textiles and clothing manufacturers have been established to capitalise on the AGOA provisions, namely Maseru, Maputsoe, Thetsane, Mafeteng and Mohale's Hoek (Figure 1). ${ }^{6}$ All of these areas are situated in the western lowlands' ecological zone where such industrial development is possible.

\footnotetext{
5 According to Vastveit (2013: 67), in 2010, the International Finance Corporation (IFC) estimated that the textile and clothing sector contributed approximately one-third to Lesotho's GDP growth between 1999 and 2008.

6 By far the largest concentration of AGOA factories is in the Maseru district, followed by Maputsoe (Kamara, 2008: 50; Vastveit, 2013: 93).
}

\section{RESEARCH METHODOLOGY}

The empirical research reported on in this article entailed an exploratory, qualitative study of communities affected by AGOA-related industrialisation. Data was gathered by means of semi-structured one-onone interviews with key informants who provided information about their experiences with, and perceptions of the regional and local spatial and economic development impacts of AGOA.

\subsection{Sampling method}

Village and town chiefs and officials from the Lesotho National Development Corporation (LNDC) ${ }^{7}$ and the Department of Trade and Industry were requested to assist with the identification of individuals whom they regarded as 'informed and knowledgeable' about the two focus areas of the study (i.e., the subnational spatial and local economic development impacts of AGOA). Purposive sampling was then used to select a body of 'key informants' from this group (Babbie \& Mouton, 2010: 166; Leedy \& Ormrod, 2013: 215; Neuman, 2012: 149).

\subsection{Sample size}

Twenty-four key informants were selected for the interviews. These informants included two senior officials of the Department of Trade and Industry; nine development planners (five spatial development planners and four economic development planners) working in the local authorities where the manufacturing firms are located; five youth representatives; two business people; five community leaders, and the Head of Investment Promotion of the LNDC. All the informants agreed to participate in the study and to have their perceptions and experiences captured.

\footnotetext{
7 The LNDC, a statutory national corporation that was established by an Act of the Lesotho Parliament in 1967, is responsible for attracting foreign industrial investment to the country and ensuring that it leads to an improvement in employment and income levels in the country (Kingdom of Lesotho, 1967; LNDC, 2016a; 2016b; Vastveit, 2013: 60-62; Kamara, 2008: 43-44). It can be regarded as the equivalent of South Africa's Industrial Development Corporation (IDC).
} 


\subsection{Data collection}

The researchers administered a semi-structured interview schedule on a one-on-one basis with the 24 respondents. These in-depth interviews allowed the informants to provide as much information on the research questions as possible. In most instances, a voice recorder was used after soliciting written permission from the respondents. In other instances, field notes were made using a pen and notebook, as the voice recordings made several of those interviewed uncomfortable in sharing their perceptions and observations. The interviews were conducted in all five industrial areas between December 2014 and June 2015. The time period that the interviews covered was taken as from the initiation of AGOA in April 2001 (i.e., when Lesotho first qualified for AGOA) until June 2014.

\subsection{Data analysis and interpretation of findings}

A structured process of data-coding, which entailed the organisation of the qualitative data into themes, was used (Leedy \& Ormrod, 2013: 158159; Neuman, 2012: 354-358). From these themes, a composite view was derived and a narrative method of data analysis used to extract insights from the data (Neuman, 2012: 360-361). In this process, the perceptions and experiences of key informants were used to construct a narrative on the regional and local economic and spatial development impacts of AGOA in Lesotho.

\subsection{Limitations}

Being a qualitative study on people's views and perceptions, it was susceptible to the biases and stereotypes of both the informants and the researchers. To counter this, issues raised and points made in the interviews were verified in subsequent interviews with other informants and by means of secondary data (i.e., articles, newspaper articles and government reports) on AGOA.

\section{FINDINGS}

The findings are structured under eight themes: direct job creation and poverty reduction; local and regional economic development spin-offs; local spatial development spin-offs; infrastructure provision, upgrading and maintenance; composition of the factory workers; migratory impacts; foreign company impacts, skills development and regional and local value chains; and local social and environmental impacts.

\subsection{Direct job creation and poverty reduction}

All the interviewees agreed that AGOA had brought positive developments to Lesotho in terms of the creation of tens of thousands of non-skilled and semi-skilled jobs and the alleviation of poverty. In several of the interviews, references were made to the impact of the factory workers on the local economy at monthend, when they "flock to the local general dealers for their groceries and other needs in their thousands". Several respondents perceived the national economic growth and taxation brought by AGOA as having assisted the Government of Lesotho in absorbing a sizeable number of people in the country's civil service.

It was generally agreed that, even though the salaries paid for the factory jobs were meagre (between 1,071 and 1,260 Maloti $8 /$ month in 2014 (Kingdom of Lesotho, 2015: 118), it was argued that it had enabled factory workers to take care of their families, it was "better than what they had had before", and it had raised their standard of living, albeit only slightly. In many instances, parents were now able to send their children to school and buy clothes for them, which they were not able to do in the past. Having a regular monthly income was also a novel positive addition to the lives of many households, and "made it possible for them to plan for their futures". In several instances, it was highlighted that workers were not only from the local area, but also from surrounding areas, and that the

\footnotetext{
8 One Maloti is equal in value to one South African Rand, which, at the time of writing this paper, was equal to 7 USA cents.
}

factories had, as such, had a wider beneficial outcome. ${ }^{9}$

The low salaries paid to the factory workers was a point of serious contention. Being below the national taxable level, it means that the factory workers do not pay taxes. On the other hand, many of those interviewed expressed the opinion that, while these wages were making a dent in the levels of poverty of the beneficiary households, it was not doing enough to contribute to regional and overall national poverty eradication.

Several of the respondents indicated that they had heard of factory workers complaining of being mistreated by their foreign employers, even though no-one pointed to a specific case that they knew of, or that had been formally reported, in which a factory worker was mistreated.

\subsection{Local and regional economic development spin-offs}

Many of the interviewees touched on the local and regional economic development spin-offs of AGOA. They indicated that several Basotho men and women were informally selling wares near the place where the factories are located, with the factory workers and security guards employed at the factories, as their primary clients. Items sold in these informal stalls include snacks, fruits, vegetables, cooked food (breakfast and lunch), airtime and, at monthend, clothing (Figure 2). However, it was pointed out that "most of these traders sell almost the same thing. They are focused on survival, not on getting rich". It was noted that, for some households, these shops had made a huge difference. As in the case of the factory workers, these households could now send their children to school, build their own houses, and, in some instances, even buy a car. $^{10}$

Several interviewees indicated that they knew of street vendors who had started as very small businesses,

\footnotetext{
9 See also the paragraph dealing with "Migratory impacts".

10 For a similar finding, see Kamara (2008: 84-85)
} 
initially selling from pavements and road reserves, and gradually 'moving up the ladder' to become medium-sized vendors with their own storerooms where they kept their wares (see Figure 5). While the shops themselves were small, these were often high-turnover businesses fuelled by high volumes of passers-by.

In several of the interviews, it was noted that the arrival of the factories had experienced a rapid expansion in the provision of public transport in the form of mini-bus taxi services by local operators. Very few local people had, however, ventured into delivery truck businesses. In addition, large retailers, especially in the Maseru and Maputsoe industrial areas, had benefitted substantially from purchases by factory workers, especially on pay days. Several filling stations and larger grocery chain stores in some settlements, constructed over the past ten to fifteen years, were also attributed to AGOA.

With regard to local agricultural production, it was observed that there were instances of local people establishing and operating smallscale agricultural projects, producing primarily vegetables (notably tomatoes, green peppers, carrots and cabbages), chicken and eggs. The produce of these operations was not only sold to the factory workers, but also to street vendors and mini-bus taxi drivers serving

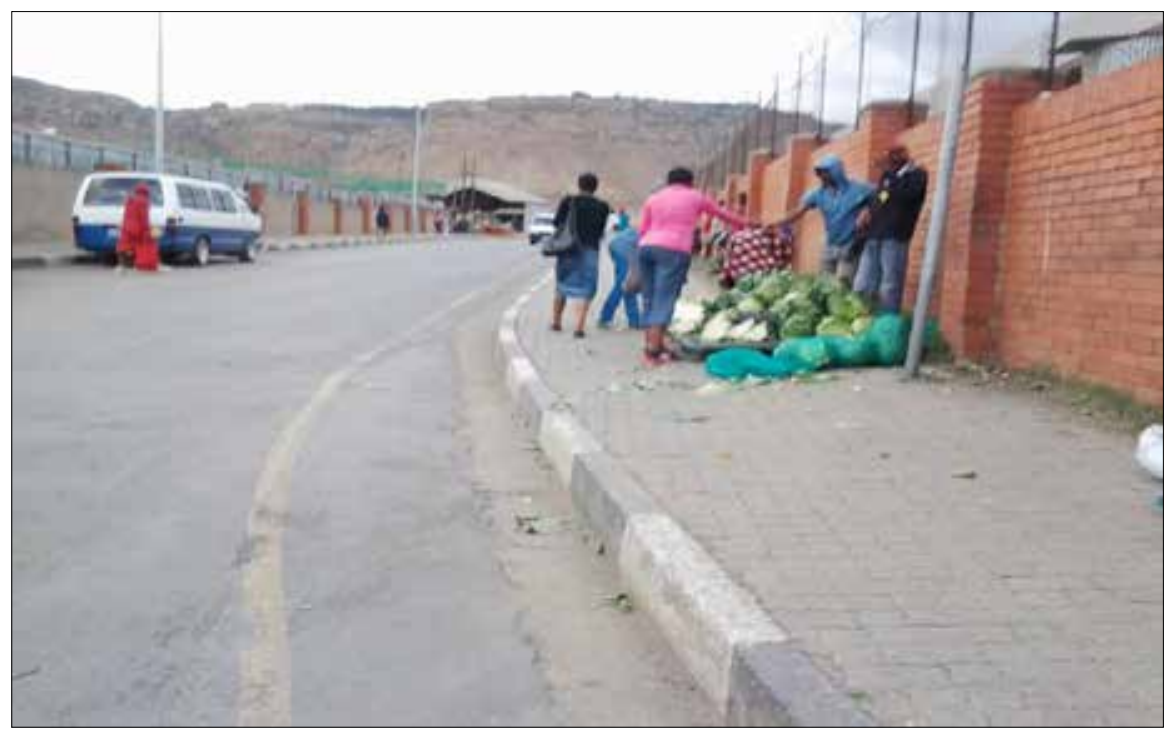

Figure 2: Street-level informal trading focused on workers in AGOA factories

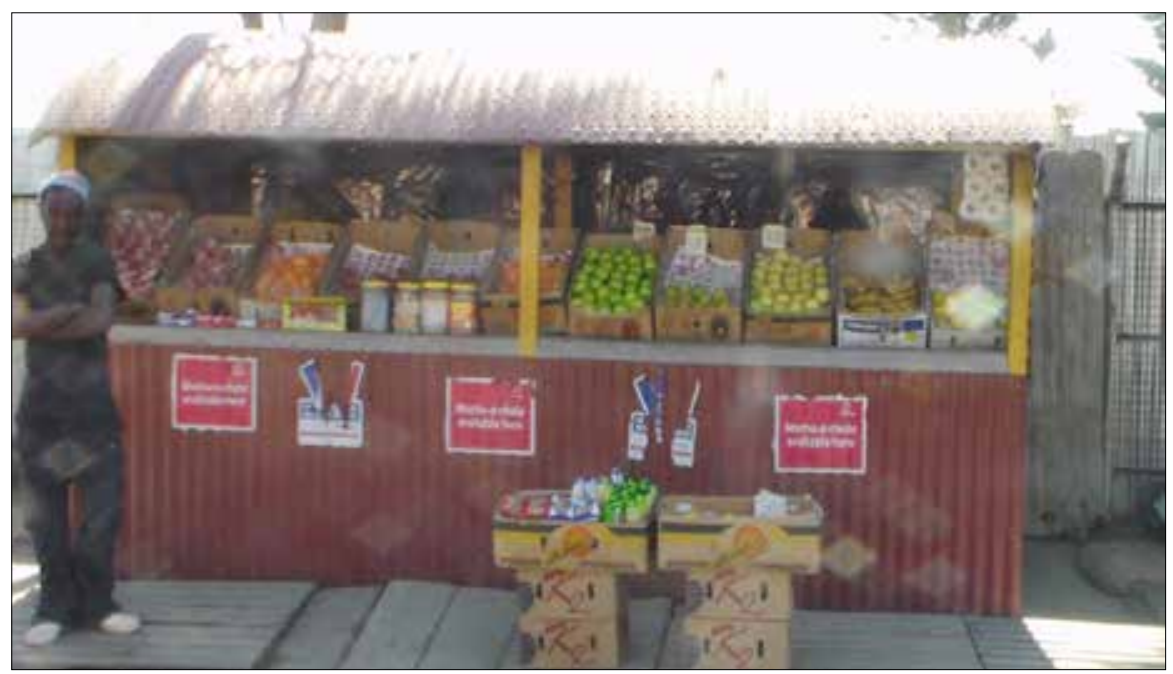

Figure 3: Informal trading in semi-permanent structures focused on workers in AGOA factories the factory workers. These small farming operations provided work opportunities for inhabitants of the settlements where the factories were located as farm labourers, and for people from further afield in Lesotho.

\subsection{Local spatial development spin-offs}

The interviewees generally agreed that AGOA had led to physical/spatial growth in the settlements where the factories are located, but that this growth was not planned for and generally haphazard in nature. It was observed that several of those who owned land in these settlements "saw land ownership as a business opportunity", and had built small units for rent to the factory workers. These units, of which there are many, are, in most instances, developed as loose-standing lines of one- and two-roomed rectangular houses, and are called 'malaene' in the local language, are informally constructed 'everywhere', and often "eat into prime agricultural land in and around the settlements" (Figures 4 and 5). ${ }^{11}$

The spatial development planners who were interviewed indicated that they had investigated what they regarded as "innovative ways of managing the haphazard development of the settlements" once the AGOA factories had been built. They had, among others, looked into alternative sites for settlement expansion and construction of factories, and for ways in which they could upgrade existing settlements where the factories had been built. They pointed out that the latter turned out to be the most likely option, due to inadequate funds and the general lack of political will for planning in local authorities. They argued that this had resulted in the illegal use and development of land that had continued unabated, and that the already huge backlogs in service provision just kept on growing and getting worse in those areas where there are severely stretched services. They added that, in some instances, houses had been illegally built in road reserves, making pedestrian movement difficult, posing health

11 For a similar set of findings, see Kamara (2008: 85-88). 
and safety risks, creating a sense of lawlessness and unmanageability, and diminishing the already low status of spatial planning and spatial planners in local authorities in the country.

\subsection{Infrastructural provision, upgrading and maintenance}

It was generally agreed that, while infrastructure connections had been made to the factories, there had not been significant infrastructure provision, upgrading and maintenance in the settlements where the factories are located. ${ }^{12}$ Infrastructure provision mainly consisted of the LNDC building factory shells that are connected to bulk water supply, sewage lines, telecommunications, and electricity, and adding a few connecting/ access roads. ${ }^{13}$ Despite their misgivings about the highly targeted and exclusionary nature of the infrastructure provision, it was observed that those living close to the factories could at least connect their units to these services in an affordable manner.

Several of the interviewees pointed to a major challenge regarding the roads that had been built to serve the factories: While roads in settlements in Lesotho are the responsibility of local authorities, they were, in most instances, constructed by the LNDC, due to the high profile of AGOA and the perceived importance of the AGOA factories for the country. However, once constructed, the maintenance and upgrading of the roads become the responsibility of the local authorities. Despite the local authorities generally doing their best, the result was a mixed bag, with these roads not being in good shape in several instances.

Interviewees also pointed out that, in some instances, local authorities had provided street lighting on the access roads to the factories, primarily for the benefit of the workers, but also for the inhabitants of the settlements, and security guards at the informal

12 This finding is supported by Kamara (2008: 91-93) and Vastveit (2013: 96).

13 See Shakya (2011) for a detailed discussion of this process of construction and support by the LNDC.

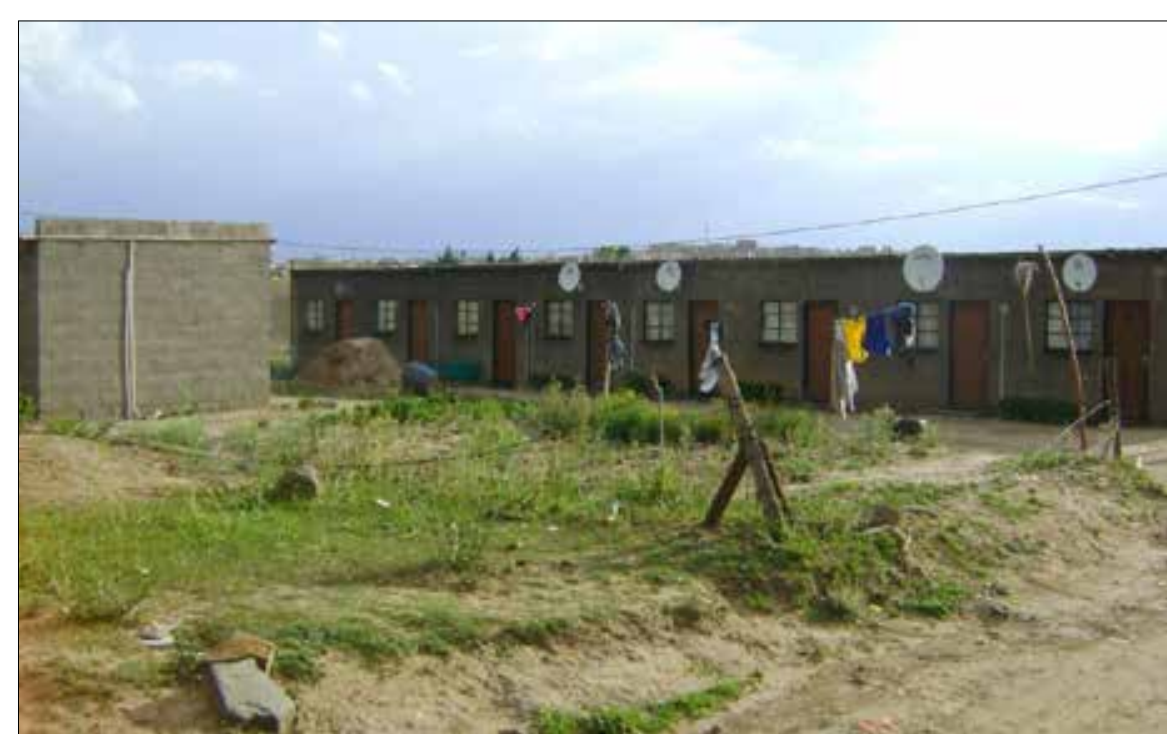

Figure 4: Housing units built for rent to workers in AGOA factories

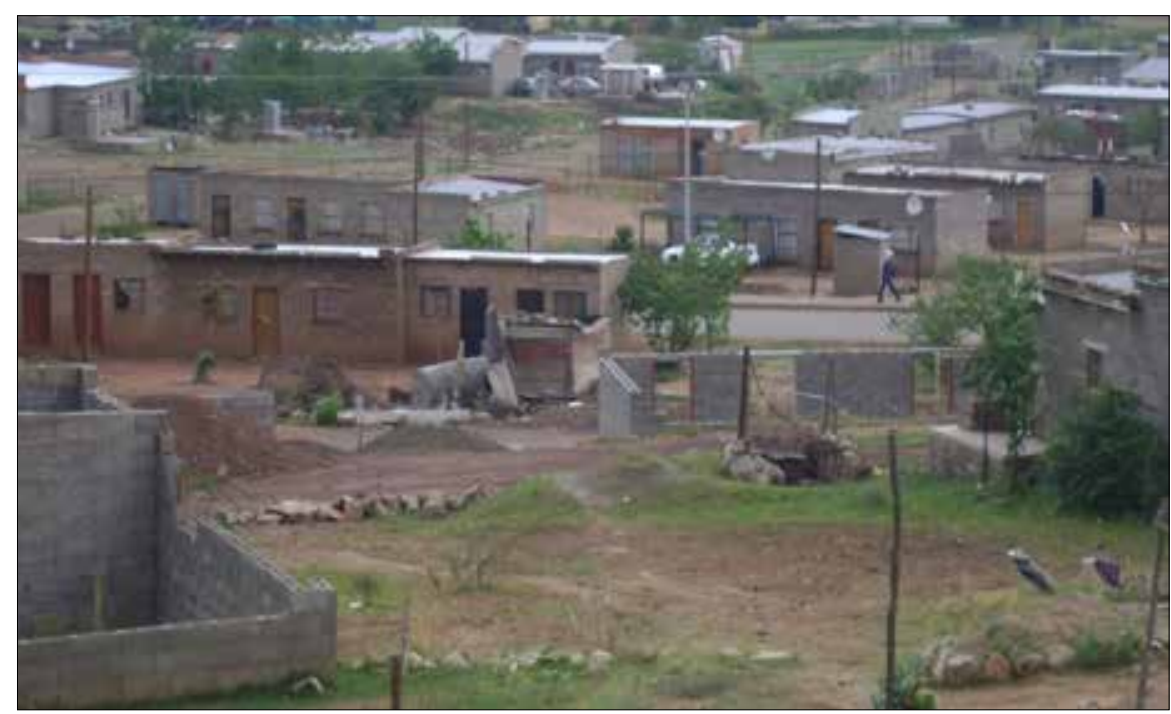

Figure 5: Unplanned, unregulated spatial development close to AGOA factories

market stalls. In general, however, there was a shared view that local authorities had not capitalised enough on, or benefitted enough from the presence of the AGOA factories, and had not used this platform to extend and upgrade services to the rest of their areas of jurisdiction. In defence of the local authorities, several of the interviewees indicated that, because AGOA had not led to broad-based economic growth, the continuing high poverty levels meant that many households still could not afford to pay for municipal services. They argued that this was the reason for the gaps and backlogs in service provision by the local authorities. One of the interviewees, who held this view, noted that, where communities could pay for services, local authorities had provided and maintained adequate infrastructure and street lighting.

It was generally held that there should have been more infrastructure development and upgrading because of AGOA, and that factory owners should have ploughed back at least some of their profits into the settlements in which they were located, in terms of service provision and the construction of schools and health facilities. As it stands, however, the AGOA factory owners are not required to do so, or to initiate or undertake any form of corporate social responsibility-led investment. 


\subsection{Composition of the factory workers}

Interviewees observed that the bulk of the factory workers are women in their early 20 s up to their late 40 s, who work as machine operators, sewers, knitters and ironers. ${ }^{14}$ The men who work at the factories are either employed as security guards or as chauffeurs to the factory managers. Legislation prohibiting child labour is strictly observed, with no interviewee indicating that $\mathrm{s} /$ he had seen or heard of any case of the law in this regard being broken at the factories.

While the majority of the factory workers are young women who have just completed their high school studies, there is an increasing tendency for university graduates to also work in the factories. ${ }^{15}$ This latter phenomenon was ascribed to the generally high levels of unemployment in the country, and the already huge and growing lack of jobs for graduates in the country. Despite the fact that many of the graduates working in these factories have the necessary qualifications, they are seldom given jobs in administration, finance or human resources management.

\subsection{Migratory impacts}

Interviewees agreed that AGOA had caused significant migration of labour in the country. Migrants came from rural areas to the five settlements to work not only in the AGOA factories, but also in the formal retail sector. In some instances, they did not find a job or lost their jobs in the formal retail sector and ultimately started their own informal businesses, or worked for other informal business operators. Given the high levels of in-migration, many of the inhabitants of the five settlements living near the factories are migrants, with "the churches and the streets in these areas generally empty and far less congested than usual during the Christmas and Easter holidays".

14 In a survey of 400 AGAO factory workers, Kamara (2008: 70) found that nearly $70 \%$ of the workers were aged thirty years or younger.

15 In a survey of 400 AGOA factory workers, Kamara (2008: 68) found that only $8.5 \%$ of workers had a post-Matric qualification. This percentage may have increased since Kamara's (2008) research was undertaken.

\subsection{Foreign company impacts, skills development and regional and local value chains}

Many of the interviewees made the point that the majority of the factories were owned by primarily Chinese and Taiwanese nationals, followed by South Africans, ${ }^{16}$ who have capitalised on the initial tax breaks and a corporate tax rate of $10 \%$, which is very low when compared to the $28 \%$ rate in South Africa. ${ }^{17}$ In addition, it was highlighted that the Lesotho government also provides skills development training to the factory workers at zero cost to the investors, and that foreign investors are free to repatriate their profits to their countries of origin without any additional taxes. Some interviewees noted that this lopsided structure leaves not only tens of thousands of workers and their dependents, but also the settlements in which the factories are located and the country, extremely vulnerable to events and decisions taken far away from the country. In fact, this happened after the global financial crash in 2008.

The interviewees agreed that primarily a lack of capital and skills prevented the Basotho from setting up and running their own factories. They also added that this would not change soon, as skills transfer from the foreign company owners and operators to the local workers was not taking place. In this regard, the language barrier was a key constraint, with foreign investors often not proficient in English. Another reason for this was that the foreign companies brought in not only their own management teams, but also interns from their countries of origin.

Several of the interviewees expressed the view that the foreigners deliberately did not transfer skills, nor offered training to Basotho factory workers, in order

16 Several of the interviewees indicated that most of the delivery trucks used by foreign companies are owned and operated by South African companies.

17 In $2014,65 \%$ of foreign investors in the textiles and garment sector were from China and Taiwan, 13\% from Hong Kong, and 5\% from South Africa (Government of Lesotho, Ministry of Trade and Industry, 2016: 19). to prevent them from starting their own businesses. ${ }^{18}$ However, some interviewees argued that AGOA had introduced the Basotho to industrial work and management, and had developed a strong work ethic in especially the younger segment of the local population. ${ }^{19}$ It was also observed that, in some factories, "workers were being taught how to spend their money wisely".

As for the small number of local start-up companies making use of AGOA, one of the officials of the Department of Trade and Industry interviewed opined that this was due to there being a lack of information among local Basotho as to how AGOA functions; an incorrect perception that "AGOA is only for use by foreigners"; established networks in the textile industry being very strong and very difficult to break into by newcomers; and local banks generally being reluctant to offer capital loans to local industrialists, with meagre family savings for many the only source of start-up finance. Another interviewee argued that the reason for local entrepreneurs not exploiting AGOA benefits was that many lacked the confidence to do so. Another suggested that "locals had misplaced negative views about the Basotho work ethic vis-à-vis that of the Chinese and the Taiwanese", and "are waiting for a success story from a local textile company" to convince them that it can be done. ${ }^{20}$

The insular nature of the foreign companies was a general point of discussion and concern. The factory owners were said to not only use their own raw materials (primarily

18 England (2013) notes that there were 38 clothing and textile producers in the country in 2013, of which 21 were from Taiwan, two from China and none from Lesotho. In 2004 , $65 \%$ and $13 \%$ of the factories in the "garment sector" were owned by foreign nationals from Taiwan and Hong Kong, respectively (Kamara, 2008: 51).

19 This view is shared by Kamara (2008: 69) who, in a survey of 400 AGOA factory workers, found that $81.2 \%$ of the workers had received informal training in the sector. He believes that this body of workers would be able to make a meaningful contribution to the manufacturing sector in Lesotho in a post-AGOA phase.

20 The two business people interviewed observed that the best way to do so was to approach a foreign firm with the request to become a subcontractor to the firm. 
from China and South Africa) in their production processes, but also to cook their own food, which "they either brought with them, or sourced from local retailers that were from their home countries". ${ }^{21}$ Hence, there were no regional or local value chains of any significance feeding into the AGOA factories, with "even basic things like broken machines still being repaired by the expatriates or being sent to their countries of origin for repairs or maintenance".

\subsection{Local social and environmental impacts}

Several of the interviewees expressed the view that the AGOA factories had caused social and environmental problems. A strongly held view among these interviewees was that youth dropped out of school or university either to take up a job in a factory, or to start their own small businesses close to the factories. In a few instances, harsh, normative opinions were expressed about the migrants, such as that some of the factory workers "were drunkards [who] came to the AGOA settlements with strange values"; some of the female factory workers "were adulterous and were destroying local families in the AGOA settlements", and "HIV and AIDS prevalence rates were high in the AGOA settlements, because of the behaviour of the migrants". ${ }^{22}$ The practice among factory workers of sharing the small informal rental units to save on expenses was viewed as a further contributor to social decay, and as creating health hazards through over-use of municipal services. With regard to environmental impacts, several of the

21 According to Vastveit (2013: 71), the lack of integration of foreign workers with the local population may also play a role in the limited linkages between the AGOA factories and local companies.

22 Whatever the cause, Lesotho has one of the world's highest HIV-positive rates, with $23.1 \%$ of the adult population being HIV positive (Keletso, 2015). HIV and AIDS are serious concerns in the settlements where the AGOA factories are located. In response to this, initiatives such as the Apparel Lesotho Alliance have been established to fight the disease in order to prevent and holistically treat workers living with HIVIAIDS on the factory floor (LENA, 2008; CBL, 2011; Kotelo, 2014; LNDC, 2014; Harding, 2015; Keletso, 2015). interviewees argued that the factories posed a fire risk, polluted the air, and contaminated streams and rivers. ${ }^{23}$ One of the interviewees mentioned that the toilets at the factories are often not clean and as such posed a health risk to both the workers at the factories and the inhabitants of the settlements.

\section{DISCUSSION}

This study sought to explore the sub-national economic and spatial impacts of AGOA in Lesotho. The main research question is engaged in a discursive and summary way in this section by making use of the findings of the study in terms of the following two sub-questions:

- Has AGOA contributed to subnational economic development in Lesotho by creating and/or strengthening local and regional value chains?

- What has the impact of AGOA been on sub-national spatial development and the state of infrastructure provision, maintenance and upgrading in the areas where the factories are located?

\subsection{Impacts of AGOA on sub-national economic development}

The findings painted a mixed picture. On the one hand, approximately 40 factories ${ }^{24}$ have been established and tens of thousands of factory and security jobs have been created. In a decade and a half, a massive clothing and textile sector has been established, and has become the largest private sector employer in the country, employing some 40,000 workers and adding approximately $20 \%$ to the country's GDP (Bureau of Statistics, 2015; Keletso, 2015). In addition, an informal rental market has arisen, and mini-bus taxi operators, small-scale informal traders, take-away-food sellers, and fresh produce farmers have

23 Vastveit (2013: 76) supports this view.

24 The exact number quoted by the LNDC in 2016 is 42 (Government of Lesotho, Ministry of Trade and Industry, 2016: 19). Morris and Sedowski (2006) specified this total as 39 , and Shakya (2011) as 60 factories. According to Payne (2011), each of these factories employs between 400 and 1,500 workers. capitalised on the market created by the factories.

On the other hand, the wages earned in the factories are very low, and their impact on the economy has primarily been in the form of survivalist household spending. Workers do not pay personal taxes, due to their low salaries, which is a saving grace for them, but means that there is no direct benefit for the State coffer and limits the ability of the State to provide services and reinvest AGOA earnings in indigenous economic development. The same applies in the case of local authorities who find it difficult to give effect to their mandates, due to the limited spending power of households in the AGOA settlements. The factories, in turn, are nearly exclusively owned and operated by foreigners (primarily Chinese and Taiwanese companies). The local economy, in terms of domestic companies feeding into the supply chains of the foreign-owned factories, has not expanded to a considerable extent. ${ }^{25}$

As it stands, there are only a handful of indigenously owned textile companies or sub-contractors; a resilient, locally owned manufacturing industry has yet to be established in the country. ${ }^{26}$ Even those Basotho who operate take-away shops in most cases buy their maize meal, meat and vegetables from Chineseowned shops. Raw materials for the factories are sourced mainly from China, and transport, maintenance and repair services are almost exclusively performed by foreign contractors. Management and senior

25 For a similar set of findings, see Fosu (2011); Mokoatsi (2011), and Rantaoleng (2014). As for the reasons behind the lack of these local value chains, Vastveit (2013: ii), in a study into Export Processing Zones (EPZs) in Kenya and Lesotho, argues that this is also due to the uncertainty surrounding the form and longevity of AGOA. She argues that these uncertainties mean that the risk is simply too high for new and emerging entrepreneurs to invest in the AGOA networks in their countries (Vastveit, 2013: ii). In addition, she argues that local entrepreneurs find it hard to compete with lower cost Asian producers, notably from India and China (Vastveit, 2013: 88). Finally, she makes the point that the limited natural resource endowment in Lesotho in the textiles sector (i.e., cotton) reduces the prospects of the establishment of local suppliers to the AGOA factories (Vastveit, 2013: 89).

26 For a similar finding, see Vastveit (2013: 68). 
positions in the factories are filled by foreigners, and the building of local skills is more in line with what is good for the factory, than it is for the workers in the sense of gaining skills that can be used elsewhere, or to start one's own company producing goods or selling services. ${ }^{27}$

While a highly productive clothing and textile manufacturing sector has been established in the country, it relies solely on AGOA, and bears all the marks of the inherited, highly skewed economic power relationships and ownership patterns. ${ }^{28}$ Should the sector suffer a severe setback, or AGOA be terminated, no indigenous value chains or generic service companies would remain on which a new or another industrial economy could be built. This worrying situation not only concerns the merits and demerits of AGOA, but also raises serious questions about the benefits, beneficiaries and durability of the positive impacts of the investment promotion and support initiatives of the LNDC, as well as the effectiveness of its more recent initiatives aimed at providing financial assistance to Basotho-owned enterprises. ${ }^{29}$

\subsection{Impacts of AGOA on sub- national spatial development}

In contrast to what often is the case with mining-related investments by large mining companies (Oranje, 2013), the construction of the AGOA factories was not accompanied by an injection by the factory owners of infrastructure investment or development spending in the settlements where they are located. Nor was there, beyond the targeted infrastructure investment in and around the factories, with the primary aim of getting the factories connected to the grid and up and running, any additional or supporting investment by the local authorities in the five settlements where the factories are located. It was literally a case of 'the parachuting in of a series of factories', with the foreign owners

27 For a similar set of findings, see Lall (2005) and Asafu-Adjaye (2011).

28 For a similar set of findings, see Kamara (2008: 21-26)

29 For a similar set of concerns, see LNDC (2016a; 2016b); Lestimes (2012), and Vastveit (2013: 62-73) and managers of the factories not living in and becoming part of the settlements, but choosing to stay in compound-style accommodation on site, next to their factories, behind security walls.

The study found that large in-migration from rural areas to the factories had resulted in the construction of rental housing units, built without planning permission, and generally without adequate provision of basic municipal services, notably potable water. These rental units, built solely with functionality and profit in mind, are small, generally not well-maintained, and add monotonous rows upon rows of hostel-type units and little else to the urban fabric and the aesthetic quality of the surrounding areas. As such, these units are aggravating the already high levels of unplanned and unserviced urban expansion in the country (Marais, 2001: 99-101). They are also leading to the capacity of municipal services being exceeded, with the resultant unhealthy sanitary conditions. In essence, the settlements close to the factories have become 'sleeper towns' for the AGOA factories with little in the sense of diversity and a mix of land uses. With the absence of local spending by the factory owners and managers in these factories, there are no multiplier effects in the surrounding settlements from the wages paid to their better paid senior foreign workers. Residential land uses, primarily in the form of rental units, are increasingly also eating into prime agricultural land, which has implications for local fresh food production and consumption, and poses a major challenge to the burgeoning urban agricultural sector in Lesotho (Nel, Hampwaye, Thornton, Rogerson \& Marais, 2009: 5, 8).

While the construction of the AGOA factories was accompanied by the provision of connecting roads and infrastructure to the factories by the LNDC, the factory owners did little else in the settlements, and made no investment in infrastructure. While those residents living close to the industrial estates benefitted from these roads and could connect to the municipal services upon payment of a small fee, it still required a payment, which not everybody could afford. At the same time, large segments of the settlements remained without services. Due to local authorities having limited funding available, they have not been able to maintain or expand the service network. Likewise, due to the local authorities' lack of appetite or political will for planning, they do not prepare plans for the development of human settlements with a wider set of objectives in mind and that are not only focused on the AGOA factories as economic hubs. ${ }^{30}$ As it stands, the local authorities are not planning for, nor are they able to control the spatial development of the areas around the factories. At the same time, given its limited regulatory powers, the state is not able to attend to the pollution of the air and water streams from the factories and to soil erosion, which has been a problem in urban settlements in Lesotho for several decades (Marais, 2001: 99-101).

\section{CONCLUSION}

While it was anticipated that AGOA would have brought considerable benefits in terms of the establishment of an industrial economy in Lesotho, the study indicated that, even though an industrial economy was created, it has largely benefitted Chinese and Taiwanese, and not indigenous companies. Regional and local value chains feeding into the AGOA factories are, to a large extent, non-existent. In addition, the continuation of the benefits brought by AGOA are directly tied to AGOA and the political decisions made around it in the USA. The research findings suggest that, while "trade and development boosting tools" such as AGOA may be useful in providing term-based job opportunities for an unskilled workforce, they will most likely not have as significant a positive impact on the local economy, the creation of an indigenous industrial class, or the building of sustainable human settlements. For this to happen, tools such as AGOA will need to focus far more on the long-term, holistic development of beneficiary

30 In a paper on urbanisation in Lesotho published on the cusp of Lesotho becoming eligible for AGOA status, Marais (2001: 102104) already raised concerns about the lack of planning capacity in 'urban Lesotho' and the dire implications this would have for settlement planning, development and servicing. 
countries, and include tailor-made requirements, in order to develop responsive, adaptive and multi-level sub-national indigenous value chains in support of this objective. This will require of beneficiary countries to change their 'development model' and approach towards foreign and indigenous investment, and make adjustments to their enabling and supporting legal, policy and programmatic instruments, as well as governing bodies and structures.

While a reformulated set of international trade-enhancing tools is thus clearly required, it is equally important that a set of regionally and locally focused supporting instruments to foster, nurture and further the development of such sub-national value chains feeding into and from the foreign investment, be co-produced with and introduced in beneficiary countries.

\section{ACKNOWLEDGEMENTS}

The authors would like to express their sincere appreciation to the peer reviewers for their valuable and insightful inputs, comments and proposals for improvement. We take full responsibility for all errors.

\section{REFERENCES LIST}

AGOA.INFO. 2016. Country Info: Lesotho. Available from: <http://agoa. info/profiles/lesotho.html> [Accessed: 6 August 2016].

ASAFU-ADJAYE, P. 2011. The opportunity that never was: Assessing the African Growth and Opportunity Act's benefits in Ghana. Legon Journal of Sociology, 3(1), pp. 35-47.

BABBIE, E. \& MOUTON, J. 2010. The practice of social research. Cape Town: Oxford University Press.

BIERMANN, S. \& ORANJE, M. 2002. Regional and economic integration with specific reference to Africa. Report prepared for the CSIR, Pretoria.

BROOKS, P. \& SHIN, J.H. 2006. China's influence in Africa: Implications for the United States. Washington D.C.: Heritage Foundation.

BUREAU OF STATISTICS. 2015. Performance of the manufacturing sector in Lesotho, third quarter 2014. Maseru: Bureau of Statistics.
CENTRAL BANK OF LESOTHO. 2011. African Growth and Opportunity Act (AGOA): Economic impact and future prospects. Economic Review, 131, pp. 1-8.

CONDON, N. \& STERN, M. 2011. The effectiveness of the African Growth and Opportunity Act (AGOA) in increasing trade from the least developed countries: A systematic review. London: University of London.

CONGRESS OF THE UNITED STATES OF AMERICA. 2000. African Growth and Opportunity Act. Washington. $106^{\text {th }}$ Congress. 18 May.

\section{CONGRESS OF THE UNITED}

STATES OF AMERICA. 2015. AGOA

Extension and Enhancement Act of 2015. Washington. $114^{\text {th }}$ Congress. 6 January.

DAILY MONITOR, 2013. AGOA renewal awaits US Congress approval. Available from: <www. monitor.co.ug/business/prosper/ agoa-renewal-awaits-us-congressapproval/-/688616/1960890/-/qkmehl/-/ index.html> [Accessed: 24 June 2014].

DAVIS, J.E. 2011. Washington's Growth and Opportunity Act or Beijing's 'Overarching Brilliance'. Will African governments choose neither? Third World Quarterly, 32(6), pp. 1147-1163. ENGLAND, A. 2013. African countries both court and worry about Chinese businesses. Financial Times, 25 March.

ENGLAND, A. 2014. Africa hopes US will build on existing trade deal. Financial Times, 5 August.FOSU, J. 2011. Sub-Saharan Africa: The challenge of integration into the global trading system. Perspectives on Global Development and Technology, 10(1), pp. 115-126.

FRANCAVILLA, C. 2015. African textile sector welcomes US trade agreement extension. This is Africa, 6 July 2015.

GOVERNMENT OF LESOTHO, MINISTRY OF TRADE AND

INDUSTRY. 2016. The AGOA response strategy for Lesotho (dated 1 June 2016). Maseru, Lesotho. Available from: <http://agoa.info/images/ documents/6186/agoa-responsestrategy-report-for-lesotho-2016.pdf> [Accessed: 5 August 2016].

GREEN, A.R. 2013. Is Africa overhyped? This is Africa, 23 February [online]. Available from: <http:// www.thisisafricaonline.com/News/ Is-Africa-over-hyped> [Accessed: 27 September 2015].
GUEST, P. 2010. Building on a qualified success. This is Africa, 28 July.

HAFNER-BURTON, E. 2005. Trading human rights: How preferential trade agreements influence government repression. International Organisation, 59(3), pp. 593-629. https://doi. org/10.1017/S0020818305050216

HARDING, A. 2015. How the US and China compete for influence in Africa. Available from: <http://www.bbc. com/news/world-africa-33643385> [Accessed: 27 September 2015].

HICKEL, J. 2011. Trading with the enemy. FPIF. Available from: <http:// fpif.org/trading_with_the_enemy/> [Accessed: 5 August 2016].

HICKEL, J. 2016. What's AGOA and why is it bad for Africa? Available from: <http://therules.org/author/jason/> [Accessed: 4 August 2016].

IRIN. 2012. Africa: AGOA uncertainty hurts textile workers. Available from: $<$ www.irinnews.org/report/95883/africaagoa-uncertainty-hurts-textile-workers> [Accessed: 24 June 2014].

KAMARA, I.B. 2008. The impact of foreign direct investment on the livelihoods of workers in the manufacturing sector in Lesotho. Unpublished dissertation (MDevStud). Bloemfontein, University of the Free State: Faculty of Economic and Management Sciences.

KARINGI, S., PÁEZ, L. \& DEGEFA, L. 2012. Report on a survey of AGOA's past, present and future prospects: The experiences and expectations of sub-Saharan Africa. ATPC.

KELETSO, P. 2015. Is Lesotho's garment industry an ethical alternative? Available from: <http://www.equaltimes. org/is-lesotho-s-garment-industryan?lan=eng\&lang=en $>$ [Accessed: 27 September 2015].

KINGDOM OF LESOTHO. 1967. Lesotho National Development Corporation Act, 1967. Maseru: Government Printer.

KINGDOM OF LESOTHO.

2015. Labour Code Wages

(Amendment) Notice, 2015. Maseru: Government Printer.

KOTELO, M. 2014. Lesotho's prospects beyond AGOA. Available from: <http://lestimes.com/lesothosprospects-beyond-agoa/> [Accessed: 27 September 2015]. 
KUSHNER, J. 2015. Africa's knowledge economy dreams still distant. This is Africa, 20 October. Available from: <http://www.thisisafricaonline. com/Policy/Africa-s-knowledgeeconomy-dreams-still-distant?ct=true> [Accessed: 16 November 2015].

LALL, S. 2005. FDI, AGOA and manufactured exports by a landlocked, least developed African economy: Lesotho. The Journal of Development Studies, 41(6), pp. 998-1022. https:// doi.org/10.1080/00220380500155254

LEEDY, P.D. \& ORMROD, J.E. 2013. Practical research: Planning and design. Tenth edition. Boston: Pearson.

LENA, 2008. AGOA benefits Lesotho's economy. Available from: $<$ http://www.gov.ls/articles/2008/ AGOA_BENEFITS_LESOTHO.php> [Accessed: 27 September 2015].

LENAGHAN, P.M. 2006. Trade negotiations or trade capitulations: An African experience. Berkeley La Raza Law Journal, 17(1), pp. 117-140.

LESOTHO NATIONAL DEVELOPMENT CORPORATION. 2014. Tour of Basotho-owned firms. LNDC Newsletter July-September 2014. Maseru: LNDC.

\section{LESOTHO NATIONAL}

DEVELOPMENT CORPORATION.

2016a. LNDC investment incentives (Why invest in Lesotho). Available from: <http://www.Indc.org.Is/ content/investment-incentiveswhy-invest-lesotho> [Accessed: 17 September 2016].

Lesotho National Development Corporation. 2016b. LNDC partial credit guarantee. Available from: $<$ http://www.Indc.org.Is/content/Indcpartial-credit-guarantee>. [Accessed: 17 September 2016].

LESTIMES. 2012. Lesotho launches M50 million Partial Credit Guarantee Fund. Lesotho Times, 11 January. Available from: <http://lestimes.com/ lesotho-launches-m50-million-partialcredit-guarantee-fund/> [Accessed: 16 November 2015].

MANOELI, S. 2012. Lesotho after AGOA: From textiles boom to sustainable development. Johannesburg: Brenthurst Foundation.

MARAIS, L. 2001. Urbanisation, urban dilemmas and urban challenges in Lesotho. Acta Academia, 33(2), pp. 88-109.MCCORMICK, R. 2006. The African Growth and Opportunity Act: The perils of pursuing African development through U.S. trade law. Texas International Law Journal, 41(2), pp. 339-384.

MOKOATSI, S. 2011. The end of AGOA: Implications and prospects for the economy of Lesotho. AfricaGrowth Agenda, July/Sept, pp. 16-18.

MORRIS, M. \& SEDOWSKI, L. 2006. Report on government responses to new post-MFA realities in Lesotho. School of Development Studies, University of KwaZulu-Natal and SALDRU, School of Economics, University of Cape Town.

MUSHITA, T.A. 2001. An African response to AGOA. Southern African Economist, 14(6), pp. 17-19.

NEL, E., HAMPWAYE, G., THORNTON, A., ROGERSON, C. \& MARAIS, L. 2009. Institutional responses to decentralisation, urban poverty, food shortages and urban agriculture. Global Development Network. Working Paper No. 36.

NEUMAN, W.L. 2012. Basics of social research: Quantitative and qualitative approaches. Third edition. Boston: Pearson.

OBASANJO, I. 2013. Aid versus trade as the model for international development. Foreign Policy Journal. Available from: <http://www. foreignpolicyjournal.com/2013/03/30/ aid-versus-trade-as-the-model-forinternational-development/> [Accessed: 8 June 2015].

ORANJE, M. 2013. The extractive industries and 'shared, inclusive and sustainable development' in South Africa. Spatium International Review, 29, pp.1-7, July. https://doi.org/10.2298/ SPAT13290010

\section{ORGANISATION FOR ECONOMIC CO-OPERATION AND} DEVELOPMENT. 2001. Glossary of statistical terms: Free trade area. Available from: <https://stats.oecd. org/glossary/detail.asp?ID=3128> [Accessed: 22 August 2015].

PAYNE, T. 2011. Where incentives mean more clothing jobs. Mail \& Guardian, 7 November. Available from: <http://mg.co.za/author/teigue-payne> [Accessed: 5 August 2016].

POPLAK, R. 2012. When a success isn't: Africa's clothing export numbers, debunked. Daily Maverick, 16 October. Available from: <http://www. dailymaverick.co.za/section/africa/> [Accessed: 3 August 2016].
RANTAOLENG, J.N. 2014. Can small dependent economies gain sustainable growth from international trade? The case of Lesotho. Africa Growth Agenda, Apr/Jun, pp. 8-10.

ROTUNNO, L., VEZINA, P-L. \& WANG, Z. 2012. The rise and fall of (Chinese) African apparel exports. CSAE Working Paper WPS/2012-12.

SCHNEIDMAN, W. 2013. Why Congress should extend the AGOA now. Available from: <www. brookings.edu/blogs/africa-in-focus/ posts/2013/10/21-african-growthand-opportunity-act-schneidman> [Accessed: 24 June 2014].

SCHNEIDMAN, W. 2015. Why AGOA should be extended for fifteen years: An Ethiopian case study. Available from: <https://www.brookings.edu/blog/ africa-in-focus/2015/03/19/why-agoashould-be-extended-for-15-years-anethiopian-case-study/> [Accessed: 16 July 2016].

SHAKYA, M. 2011. Apparel exports in Lesotho: The state's role in building critical mass for competitiveness. In: Chuchan-Pole, P. \& Angwafo, M. (Eds). Yes Africa can: Success stories from a dynamic continent. Washington, DC: World Bank Publications, pp. 219-230.

SMITH, A.D. 2009. Is trade not aid, the answer for Africa? Donors are now focusing less on charity and more on the continent's small entrepreneurs. The Guardian. Available from: <http:// www.theguardian.com/business/2009/ may/25/africa-entrepreneurs-charity> [Accessed: 15 June 2015].

VASTVEIT, L.K. 2013. Export processing zones in sub-Saharan Africa - Kenya and Lesotho. Unpublished thesis (MA). Norway, University of Bergen: Department of Economics.

WAX, E. 2003. Ugandans seek greater gains. The Washington Post, 6 July.

WILLIAMS, B.R. 2014. African Growth and Opportunity Act: Background and reauthorisation. Washington: Congressional Research Service.

WROBLEWSKA, A.B. 2015. The limits of AGOA in South Africa. This is Africa, 31 July.

ZAPPILE, T.M. 2011. Non-reciprocal trade agreements and trade: Does the African Growth and Opportunity Act (AGOA) increase trade? International Studies Perspectives, 12(1), pp. 46-67. https://doi. org/10.1111/j.1528-3585.2010.00419.x 